\title{
Suppression of Knapweed Invasion by Crested Wheatgrass in the Dry Interior of British Columbia
}

\author{
DENIS E. BERUBE AND JUDITH H. MYERS
}

\begin{abstract}
We resampled an experimental plot established 11 years previously in the dry interior of British Columbia to test the ability of crested wheatgrass and Russian wild rye to suppress the invasion of diffuse knapweed. Knapweed density was high in non-seeded plots, moderate in Russian wild rye plots, and very low in crested wheatgrass plots. Watering experiments indicated that lack of soil moisture resulted in high seedling mortality and prevented knapweed invasion into crested wheatgrass plots. Diffuse knapweed reinvaded a similar experimental area in a higher rainfall region of B.C., which shows that the same cultural practices will have different effects on knapweed suppression under different climatic regimes.
\end{abstract}

Diffuse knapweed (Centaurea diffusa) has become an important rangeland weed in the dry interior of British Columbia (Harris and Cranston 1979). The rapid invasion of rangeland by this weed shows it to be a vigorous competitor with the native vegetation. But an unanswered question is whether knapweed can invade range in good condition, or only range that has been disturbed or overgrazed.

As part of a study to investigate this question, we examined the status of experimental areas set up by the British Columbia Ministry of Agriculture and the Agriculture Canada Research Station, Kamloops, in 1967, 11 years prior to our visit. These areas were treated with picloram (4 amino-3,5,6, trichloropiclinic acid) and planted in crested wheatgrass (CWG), Agropyron cristatum, and Russian wild rye (RWR), Elymus junceus. One experimental area is near Cache Creek, B.C., where the precipitation is only $20 \mathrm{~cm}$ a year, and another near Pritchard, B.C., which is somewhat moister with an annual precipitation of approximately $33 \mathrm{~cm}$ a year. Both areas are in the brown chernozemic soil zone and the Ponderosa pine- bunchgrass biogeoclimatic zone (Farley 1979) and the lower grassland (Agropyron-Artemisia) vegetation zone (van Ryswyk et al. 1966).

These experiments allowed us to investigate the ability of diffuse knapweed to invade rangeland planted in grass and protected from grazing. The difference in moisture regimes between the areas provided an additional dimension to the analysis. Specifically we wanted to know if diffuse knapweed would invade grassland in the absence of grazing.

\footnotetext{
Authors are at 115 Connaught Crescent, Regina, Canada S4T 6M8; and Institute of Animal Resource Ecology and Department of Plant Science, University of British Columbia, Vancouver, Canada V6T iW5.

Authors wish to thank Dr. Alastair Mclean of the Range Research Station. Agriculture Canada, Kamloops, B.C., for providing facilities and advice to make our work on on knapweed possible. Kate Lindsay and Peter Morrison provided field assistance and Mr. Alf Bawtry, B.C. Ministry of Agriculture, first told us about this location and provided crucial information about the original experimental design for which we are most grateful. This work was supported by an Agriculture Canada EMR grant and research contract.

Manuscript received June 9, 1980
}

\section{Study Plots}

The study sites are described by Hubbard (1975) and additional valuable details were provided by Mr. Alf Bawtry (B.C.M.A., Kamloops). The Cache Creek site is adjacent to the Bonaparte Indian Reserve, approximately $6.5 \mathrm{~km} N$ of Cache Creek. In spring 1967 , a knapweed infested area was treated with picloram at 0.14 , $0.28,0.42$ and $0.56 \mathrm{~kg} / \mathrm{ha}$ and planted with Russian wild rye and crested wheatgrass using a rangeland drill. Similar treatments were applied in 1969 at Pritchard. We first visited the Cache Creek site in early May 1978 and the nonuniform pattern of knapweed invasion was so striking that we decided to quantify the pattern and set up seeding experiments in an attempt to determine what was limiting the spread of diffuse knapweed at the site. The Pritchard plot was completely reinvaded by knapweed and we only record that observation and discuss the significance here.

\section{Methods}

On May 15 we set up three pairs of $1 / 4-\mathrm{m}^{2}$ plots in the CWG area to determine if water or the soil seed bank was limiting knapweed establishment here. We seeded two of these three pairs with 400 diffuse knapweed seeds. Prior to seeding, the surface of one pair of plots was broken to a depth of $2-3 \mathrm{~cm}$ with a rake. The third pair was not seeded, but the surfaces of both plots were broken. One member of each pair received 9 liters $\mathrm{H}_{2} \mathrm{O}$ at weekly intervals through June.

On June 2, an additional 6 pairs of $1 / 4-\mathrm{m}^{2}$ plots were set up in the CWG to test the effects of watering. The surfaces of all the plots were broken, and each was seeded with 1000 diffuse knapweed seeds. Three of the pairs were mulched with a $2-3 \mathrm{~cm}$ layer of hay. At sowing one member of each pair was watered with 9 liters $\mathrm{H}_{2} \mathrm{O}$. At subsequent weekly waterings through June, mulched plots received only 4.5 liters $\mathrm{H}_{2} \mathrm{O}$ instead of the 9 liters put on the unmulched plots. During June and on 14 July, the plots were checked for the presence of knapweed seedlings. The plots were checked again on May 25 and July 25, 1979.

On May 30, 1978 we measured diffuse knapweed density along 7 , 120-m long transects spaced $10 \mathrm{~m}$ apart (Fig. 1). Diffuse knapweed seedlings, rosettes and bolting stems were counted on the same $1-\mathrm{m}^{2}$ quadrats at $10-\mathrm{m}$ intervals along each transect. In addition, knapweed density was measured on $1 / 4-\mathrm{m}^{2}$ quadrats located at 10 - $\mathrm{m}$ intervals in a shallow gully which crossed the site (Fig. 1).

Because of the significant departure from the assumption of homogeneity of variances of the knapweed densities on the plots, analysis of variance was inappropriate. Instead, we have used the Hodges-Lehmann test (Marascuilo and McSweeney 1977), which is a non-parametric test designed to control for block differences in a randomized block design. Block effects are removed by aligning the observations within each block with respect to the block mean. This test requires an equal number of observations per cell when a 


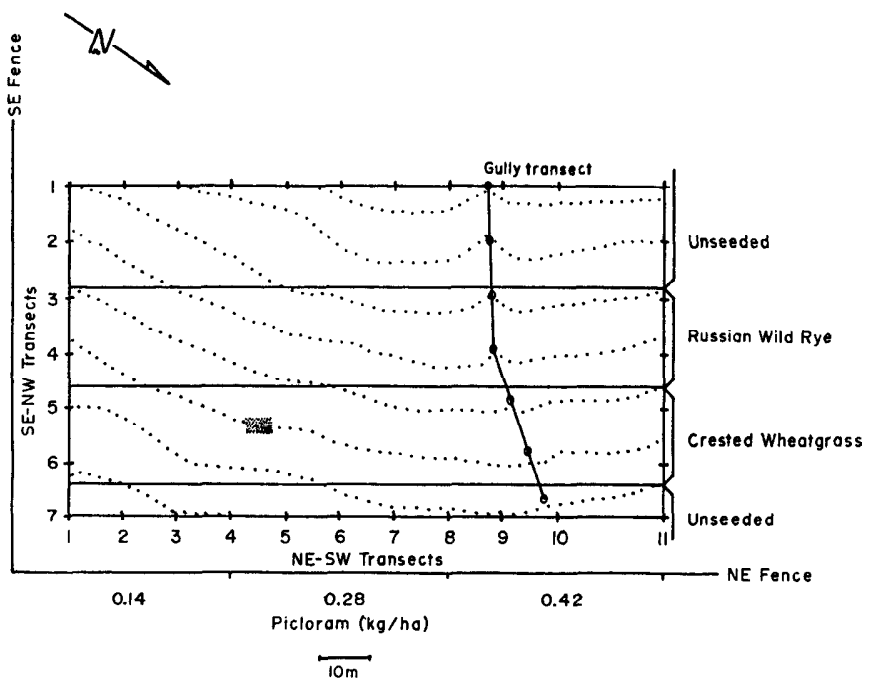

Fig. 1. Map of study site. Dotted lines show contour; contour interval $=I$ $m$. Shaded rectangle shows approximate location of knapweed seeding plots.

test for interaction is desired. We met this requirement by omitting from the analysis counts made along transects 4 and $8 \mathrm{NE} / \mathrm{SW}$, and $7 \mathrm{SE} / \mathrm{NW}$. These transects were omitted because they were near treatment boundaries. The data were blocked according to picloram treatment levels, and differences in the knapweed densities in the seeded and unseeded plots were compared. Knapweed seedling, rosette, and stem densities were each analyzed.

\section{Results}

Knapweed densities varied significantly with the grass seeding treatment (Table 1) at the Cache Creek site. Diffuse knapweed was almost excluded from the CWG areas and the density in the RWR areas was approximately $1 / 3$ that on the unseeded plots. Crude estimates of plant survival can be obtained by dividing the number of rosettes and stems by the number of seedlings. This indicates that most of the variation among sites must occur at the time of seedling establishment since later survival was similar in all areas. The highest knapweed density occurred in the ditch which ran almost parallel to the sampling transects. Even here the knapweed density was reduced in the CWG area (Table 1).

There was no significant interaction between the seeding and picloram treatments. Therefore, significant differences among the grass seeding treatments were due entirely to main effects.

The hay mulches were effective in reducing evaporation from the soil surface, and mulched plots remained moist between waterings. Knapweed seed germination was good on the mulched, watered plots, but seedling mortality was almost $100 \%$, possibly the result of the heavy fungal growth under the mulch. On one of these plots, a single rosette was produced at the edge of the mulch. Germination took place on the unwatered, mulched plots as well, and this occurred during and following a cool, showery period in the first week of July. Limited germination occurred on both watered and
Table 2. Total number of diffuse knapweed seedlings and rosettes counted approximately 1 year after tretment (May 25, 1979) on sowed $1 / 4-\mathrm{m}^{2}$ plots. Unsowed plots and mulched plots produced no seedlings.

\begin{tabular}{|c|c|c|c|}
\hline & \multicolumn{2}{|c|}{$\begin{array}{l}\text { May Plots } \\
\text { Surface }\end{array}$} & \multirow{2}{*}{$\begin{array}{c}\text { June Plots } \\
\text { Mean of } \\
\text { Unmulched replicates } \\
\text { (S.D.) } \\
\end{array}$} \\
\hline & Broken & Unbroken & \\
\hline Watered & 23 & 111 & $79.3(19.7)^{1}$ \\
\hline Unwatered & 42 & 11 & $121.7(43.0)$ \\
\hline
\end{tabular}

'Broken/ unbroken, $X^{2}{ }_{1}=21.25, P<0.01$; watered/unwatered $X{ }_{1}=4.15, P<0.05$, May; $X 2_{1}=26.75, P<0.001$, June.

unwatered, unmulched, June plots during the showery period in early July. Only a single seedling was found on any of the May plots.

The number of seedlings and rosettes on the plots on May 25, 1979 , is shown in Table 2 . There were no knapweed plants on the unseeded May plots or on the mulched, June plots. Among the unmulched, June plots, unwatered plots had significantly more seedlings than watered plots $(P<0.001)$. This was also truc for the May plots $(P<0.05)$. Among the May plots, significantly fewer seedlings occurred on plots with undisturbed surfaces $(P<0.001)$. On July 25,1979 , only a single seedling remained on any of these plots.

\section{Discussion}

The Cache Creek area receives only about $20 \mathrm{~cm}$ of precipitation annually. Approximately $6 \mathrm{~cm}$ of rain falls in the summer months of June, July, and August: about $50 \%$ in June and $50 \%$ more or less equitably distributed throughout July and August from convectional storms (R. Williams, personal communication).

May/June, and to a lesser extent, August/September, are critical periods in the diffuse knapweed life cycle when seeds normally germinate and seedlings become established. Adequate moisture at one or the other of these times is essential for seedling survival. Once seedlings have become established as rosettes, however, they are remarkably drought resistant.

The lack of sufficient moisture for successful seedling establishment appears to be the primary factor limiting the spread of diffuse knapweed at the Cache Creek site. This is shown by the knapweed seeding experiments. Germination in June 1978 was good on the mulched plots, but poor on the unmulched plots. In May 1979 only 3-15\% of the seed sowed the previous spring appeared as seedlings or rosettes, and by mid July 1979 these all had died. In addition there appeared to be an inverse relationship between elevation and knapweed density. Lower, and therefore moister, areas seemed to be associated with more successful germination and rosette establishment. This was especially true for the gully.

The significantly lower diffuse knapweed densities in the CWG and RWR are probably the result of reduced soil moisture created by these plants, especially by CWG. This species grows ea rly in the spring and withdraws soil moisture then. The poorer seedling to rosette survival in the CWG area implicates moisture as the important cause of mortality since at this stage diffuse knapweed is most sensitive to a water deficit.

Table 1. Mean number of diffuse knapweed plants in $\mathrm{m}^{2}$ quadrats taken across grass seeding treatments at the Cache Creek site. Quadrats in the gully were $1 / 4 \mathrm{~m}^{2}$. Standard errors are given in parentheses.

\begin{tabular}{|c|c|c|c|c|c|c|}
\hline & $N$ & Seedlings & Rosettes & $\begin{array}{l}\text { Proportion } \\
\text { surviving }\end{array}$ & Stems & $\begin{array}{c}\text { Proportion } \\
\text { surviving }\end{array}$ \\
\hline No seed & 18 & $60.06(15.89)^{\mathrm{ab1}}$ & $28.11(5.74)^{d}$ & 0.47 & $5.39(1.62)^{\mathrm{ef}}$ & 0.09 \\
\hline Crested wheatgrass & 18 & $1.78(1.13)^{\mathrm{ac}}$ & $0.39(0.22)^{d}$ & 0.22 & $0.00(0.00)^{e}$ & 0.00 \\
\hline Russian wild rye & 18 & $24.39(12.64)^{b c}$ & $8.33(1.83)^{d}$ & 0.34 & $1.17(0.49)^{\mathrm{f}}$ & 0.05 \\
\hline Gully total & 7 & $109.29(30.70)$ & $15.57(6.75)$ & 0.14 & $3.29(2.02)$ & 0.03 \\
\hline Gully-CWG & 2 & $2.50(2.50)$ & $1.50(0.50)$ & 0.60 & $0.00(0.00)$ & 0.00 \\
\hline
\end{tabular}

'Means followed by the same letter are significantly different at $P<.05$ or less, except $\mathrm{b}$ and $\mathrm{c}$, which are significant at $P<0.1$. 
Watering plots sowed to diffuse knapweed produced an effect opposite to what we expected. During the spring and summer of 1978, seedling counts did not differ between watered and unwatered, unmulched plots. However, in the spring of 1979, there were more seedlings on the unwatered plots. Thus, periodic soil wetting and drying may decrease the viability of knapweed seed in the soil. Apparently, seeds on the sowed plots differed in the amount of moisture or time necessa ry for ge rmination, and those seeds which germinated most readily following wetting, died when the soil quickly dried out. This was especially true for the seed sowed directly on the unbroken soil surface. Because summer precipitation in this region is from convectional storms, periodic wetting followed by rapid drying is characteristic of summer conditions, and this could deplete the seed bank.

The maintenance of diffuse knapweed stands in dry regions like Cache Creek appears to depend on the precarious relationship between adequate soil moisture and sufficient knapweed seed. The knapweed gall flies Urophora affinis and $U$. quadrifasciata, released for biocontrol of diffuse knapweed in British Columbia, have reduced diffuse knapweed seed production at their release sites to about 375 seeds per $1 / 4 \mathrm{~m}^{2}$ (Harris 1980). Such a reduction in seed production at the Cache Creek site may supplement the competitive advantage of the grasses and allow knapweed control even with grazing.

The complete reinvasion of knapweed into the CWG at the Pritchard site was in sharp contrast observed at Cache Creek. We believe this to be due to the increased availability of soil moisture at Pritchard. Pritchard receives about $50 \%$ more summer precipitation than does Cache Creek, with much of this falling in June, the critical month for diffuse knapweed seedling establishment. Cooler temperatures and better soil structure also contribute to the increased moisture availability, and therefore increased seedling survival.

Unlike at Cache Creek, diffuse knapweed often becomes less dense in gullies and depressions in the Pritchard area (Berube, unpublished data). This suggests that diffuse knapweed is able to outcompete other vegetation over a relatively narrow range of moisture conditions. Knapweed growing in areas where it is marginally adapted is undoubtedly stressed. It is in these areas where control is likely to be most easily achieved.

Popova (1960) reported that fertilization encouraged diffuse knapweed over other vegetation. However, the rate of soil moisture withdrawal by grasses can be greatly increased by the application of nitrogen fertilizers (Sneva et al. 1958, Black 1968, Williams et al. 1979). This suggests that fertilization may be effective in stressing knapweed where conditions are drier than optimal even though it may not under moister conditions.

Biological control of weeds is based on the premise that insect feeding stresses plants and eventually causes a reduction in weed density. If different stresses on plants are cumulative, cultural practices which lower the competitive ability of weeds should enhance the effectiveness of biological control. In drier areas of British Columbia diffuse knapweed is stressed by erratic rainfall associated with summer thunderstorms causing seed germination followed by seedling death as the soil dries. Crested wheatgrass increases the stress on knapweed by using soil moisture for early spring growth. The seed feeding flies Urophora may provide sufficent additional stress on knapweed to cause a major reduction in plant density in these dry areas. Comparative studies on the effectiveness of biological control agents on plants exposed to varying degrees of environmental and cultural stress are necessary.

\section{Literature Cited}

Black, A.L. 1968. Nitrogen and phosphorus fertilization for production of crested wheatgrass and native grass in northeastern Montana. Agron. J. 60:213-216.

Farley, A.L. 1979. Atlas of British Columbia, Univ. British Col. Press, Vancouver.

Harris, P. 1980. Establishment of Urophora affinis Frfld. and U. quadrifasciata (Meig.) (Diptera: Tephritidae) in Canada for the biological control of diffuse and spotted knapweed. Z. ang. Ent. 89:504-514.

Harris, P., and R. Cranston .1979. An economic evaluation of control methods for diffuse and spotted knapweed in western Canada. Can. J. Plant. Sci. 59:375-382.

Hubbard, W.A. 1975. Increased range forage production by reseeding and the chemical control of knapweed. J. Range Manage. 28:406-407.

Marascuilo, L.A., and M. McSweeney. 1977. Nonparametric and Distribution-Free Methods for the Social Sciences. Brooks/Cole Publishing Company, Monterey, California. xvii $+556 \mathrm{p}$.

Popova, A.Y. 1960. Centaurea diffusa Lam., a steppe-pasture weed in the Crimea. Bot. Zhu. (Moscow) 45:1207-1213. English trans. No. 1495707, Translation Bureau, Dept. Secretary of State, Ottawa, Canada.

Ryswyk, van A.L., A. McLean, and L.S. Marchand. 1966. The climate, native vegetation, and soils of some grasslands at different elevations in British Columbia. Can. J. Plant Sci. 46:35-50.

Sneva, F.A., D.N. Hyder, and C.S. Cooper. 1958. The influence of ammonium nitrate on the growth and yield of crested wheatgrass on the Oregon high desert. Agron. J. 50:40-44.

Williams, R.J., K. Broersma, and A.L. van Ryswyk. 1979. The effects of nitrogen fertilization on water use by crested wheatgrass. J. Range Manage. 32:98-100. 